\title{
Feeding preferences of West Indian manatees in Florida, Belize, and Puerto Rico as indicated by stable isotope analysis
}

\author{
Christy D. Alves-Stanley ${ }^{1}$, Graham A. J. Worthy ${ }^{1,2, *}$, Robert K. Bonde ${ }^{3}$ \\ ${ }^{1}$ Physiological Ecology and Bioenergetics Lab, Department of Biology, University of Central Florida, \\ 4000 Central Florida Blvd., Orlando, Florida 32816, USA \\ ${ }^{2}$ Hubbs-SeaWorld Research Institute, 6295 Sea Harbor Dr., Orlando, Florida 32821, USA \\ ${ }^{3}$ US Geological Survey, Florida Integrated Science Center, 2201 NW 40th Terrace, Gainesville, Florida 32605, USA
}

\begin{abstract}
The endangered West Indian manatee Trichechus manatus has 2 recognized subspecies: the Florida T. m. latirostris and Antillean T. m. manatus manatee, both of which are found in freshwater, estuarine, and marine habitats. A better understanding of manatee feeding preferences and habitat use is essential to establish criteria on which conservation plans can be based. Skin from manatees in Florida, Belize, and Puerto Rico, as well as aquatic vegetation from their presumed diet, were analyzed for stable carbon and nitrogen isotope ratios. This is the first application of stable isotope analysis to Antillean manatees. Stable isotope ratios for aquatic vegetation differed by plant type (freshwater, estuarine, and marine), collection location, and in one instance, season. Carbon and nitrogen isotope ratios for manatee skin differed between collection location and in one instance, season, but did not differ between sex or age class. Signatures in the skin of manatees sampled in Belize and Puerto Rico indicated a diet composed primarily of seagrasses, whereas those of Florida manatees exhibited greater regional variation. Mixing model results indicated that manatees sampled from Crystal River and Homosassa Springs (Florida, USA) ate primarily freshwater vegetation, whereas manatees sampled from Big Bend Power Plant, Ten Thousand Islands, and Warm Mineral Springs (Florida) fed primarily on seagrasses. Possible diet-tissue discrimination values for ${ }^{15} \mathrm{~N}$ were estimated to range from 1.0 to $1.5 \%$. Stable isotope analysis can be used to interpret manatee feeding behavior over a long period of time, specifically the use of freshwater vegetation versus seagrasses, and can aid in identifying critical habitats and improving conservation efforts.
\end{abstract}

KEY WORDS: Stable isotope - West Indian manatee $\cdot$ Seagrass $\cdot$ Aquatic plants $\cdot{ }^{13} \mathrm{C} \cdot{ }^{15} \mathrm{~N} \cdot$ Feeding ecology · Mixing model

\section{INTRODUCTION}

The West Indian manatee Trichechus manatus is 1 of only 2 extant sirenian species (T. manatus and T. senegalensis) that occupy marine, estuarine, and freshwater habitats (Hartman 1979, Best 1981). This herbivorous species has 2 recognized subspecies, the Florida manatee T. m. latirostris and the Antillean manatee T. m. manatus. Relatively little is known about manatee feeding ecology and habitat use outside of Florida since they often occupy shallow, turbid water. Even in Florida, most feeding studies have been con- ducted in captivity (e.g. Marshall et al. 2000) or in clear waters near natural springs (e.g. Hartman 1979). Reliable population estimates for both subspecies remain elusive (Lefebvre et al. 1995, UNEP Caribbean Environment Programme 1995, USFWS 2001), and a better understanding of manatee feeding ecology and its relation to habitat use is essential in order to improve conservation efforts.

Although there are few morphological differences between the 2 subspecies (Antilleans tend to be smaller in body size than Florida manatees and have differing skull features; Converse et al. 1994), there are 
many other differences in habitat, climate, and population size that have unique effects on the success of each subspecies. Both subspecies appear to require regular year-round access to a freshwater source (Lefebvre et al. 1989, Olivera-Gomez \& Mellink 2005), a requirement that is likely a result of osmoregulatory constraints (Ortiz et al. 1998, 1999). Winter habitat use by Florida manatees is primarily influenced by water temperature, whereby physiological constraints require that they aggregate at natural (springs) and/or artificial (power plant outflows) warm water sources when water temperatures drop below $20^{\circ} \mathrm{C}$ (Irvine 1983, Worthy et al. 2000, Bossart et al. 2003). This pattern is unnecessary for Antillean manatees since their range lies in the tropics where water temperatures are more constant. Population estimates for the Florida manatee suggest counts as high as 3807 individuals (FWC 2009), whereas Antillean manatees are thought to number fewer than 100 individuals in most countries (summarized by O'Shea \& Salisbury 1991). The largest Antillean manatee population is in Mexico and is currently estimated at around 1000 to 2000 individuals (Quintana-Rizzo \& Reynolds 2007). A 2002 aerial survey in Belize indicated a population of 338 individuals (Auil 2004), and recent evidence suggests a population in Belize of between 400 and 700 manatees (QuintanaRizzo \& Reynolds 2007). In Puerto Rico, manatee distribution is patchy, and population counts suggest a population of about 250 individuals (Slone et al. 2006).

Manatees are considered to be generalist feeders and are known to consume approximately 60 different species of vegetation in marine, estuarine, and freshwater habitats (Hartman 1979, Best 1981, Bengtson 1983). Florida manatees appear to exhibit regional and possibly seasonal differences in diet composition (Reich \& Worthy 2006). Because of the previously mentioned habitat and climate differences between the 2 subspecies, seagrasses tend to make up a much larger portion of the manatee diet in Puerto Rico than freshwater and/or estuarine vegetation (Mignucci-Giannoni $\&$ Beck 1998). Very little is known of the feeding habits of manatees in Belize, but seasonal differences in lagoon water levels may lead to changes in habitat use (Morales-Vela et al. 2000, Auil et al. 2007) and consequently diet composition. Little research has been done on the Antillean subspecies, and expanded effort is crucial to provide measures on which to base conservation plans.

It can be challenging to evaluate feeding behavior and habitat use in marine mammals since they are difficult to observe directly and may have expansive migration patterns. A variety of methods have been used, including satellite tracking (e.g. Laidre et al. 2003), stomach content analysis (e.g. Spitz et al. 2006), fecal analysis (e.g. Sinclair \& Zeppelin 2002), and fatty acid signature analysis (e.g. Iverson et al. 1997). Some complications involved in these methods include logistics, cost, invasiveness, difficulty in identifying and estimating the proportion of diet components, and the inability to assess long-term feeding history. The application of stable isotope analysis to ecological research has expanded in recent years (reviewed by Kelly 2000) and has some advantages over these techniques. Isotopic ratios of local food webs are incorporated into the tissues of the consumer and can be used to predict diet composition, the trophic level at which the consumer is feeding, and even habitat use and migratory patterns (e.g. Deniro \& Epstein 1978, 1981, Fry 1981, Peterson \& Fry 1987, Hobson 1999). Tissues such as hair and skin can be easily sampled from live animals, and both recent and long-term feeding history can be assessed by analyzing tissues that incorporate nutrients at different rates. To accurately interpret isotopic results, it is important to know the diet-tissue discrimination value (the difference in isotope ratios between the diet and consumer tissue) as well as the turnover rate (the amount of time required to incorporate isotopes from the diet into the tissue). Previous studies have calculated or estimated diet-tissue discrimination values and turnover rates for carbon and nitrogen isotopes in manatee skin (Ames et al. 1996, Reich \& Worthy 2006, Alves-Stanley \& Worthy 2009), allowing for more accurate interpretation of stable isotope data.

The present study is the first to apply stable isotope analysis to Antillean manatees and further expands the assessment of the feeding ecology of Florida manatees. The objectives of this study were to (1) analyze $\delta^{13} \mathrm{C}$ and $\delta^{15} \mathrm{~N}$ values in epidermal samples collected from free-ranging manatees in Florida, Belize, and Puerto Rico, (2) compare signatures in the skin to those of freshwater, estuarine, and marine vegetation within the presumed manatee diet, and (3) assess possible differences in feeding preferences by region, sex, age class, and season.

\section{MATERIALS AND METHODS}

Sample collection. Samples of aquatic vegetation were collected within Florida (Table 1, Fig. 1) during the summer of 2001, the fall, winter, and spring of 2004 and 2005 (Charlotte Harbor: $\mathrm{n}=15$; Crystal River: $\mathrm{n}=5$; Indian River Lagoon: $\mathrm{n}=21$, St. Johns River near Blue Spring: $\mathrm{n}=29$; Tampa Bay: $\mathrm{n}=16$; and Ten Thousand Islands: $\mathrm{n}=15$ ) and from Belize (Table 1, Fig. 1) during the summer of 2002 (Drowned Cayes: $\mathrm{n}=18$ ). Plant collections from Puerto Rico were not possible due to study constraints. Each vegetation sample consisted of 2 to 3 whole plants or 20 to 30 seagrass blades for each available species at each site. Collection sites in the St. 
Table 1. Aquatic plant species (freshwater, estuarine, and seagrasses) collected in the present study. Sites: SJ: St. Johns River, CR: Crystal River, IR: Indian River, CH: Charlotte Harbor, TB: Tampa Bay, TI: Ten Thousand Islands, DC: Drowned Cayes

\begin{tabular}{|c|c|c|c|c|c|c|c|c|}
\hline \multirow{3}{*}{ Species } & \multirow{3}{*}{$\begin{array}{l}\text { Fresh } \\
\text { SJ }\end{array}$} & \multirow{2}{*}{\multicolumn{2}{|c|}{ Estuarine }} & $\mathrm{a}$ & & & & \multirow{3}{*}{$\begin{array}{c}\text { Belize } \\
\text { Seagrass } \\
\text { DC }\end{array}$} \\
\hline & & & & & Sea & $\mathrm{ss}-$ & & \\
\hline & & CR & IR & $\mathrm{CH}$ & IR & TB & TI & \\
\hline Alternanthera philoxeroides (alligatorweed) & $\mathrm{X}$ & & & & & & & \\
\hline Chara sp. (stonewort) & & $\mathrm{X}$ & & & & & & \\
\hline Eichhornia crassipes (water hyacinth) & $\mathrm{X}$ & & & & & & & \\
\hline Gracilaria sp. (red alga) & & & $\mathrm{X}$ & & $\mathrm{X}$ & & & \\
\hline Halodule wrightii (shoal grass) & & & $\mathrm{X}$ & $\mathrm{X}$ & $\mathrm{X}$ & $\mathrm{X}$ & $\mathrm{X}$ & $\mathrm{X}$ \\
\hline Halophila engelmannii (star grass) & & & & & & & $\mathrm{X}$ & \\
\hline Hydrilla verticillata (hydrilla) & & $\mathrm{X}$ & & & & & & \\
\hline Hydrocotyle sp. (pennywort) & $\mathrm{X}$ & & & & & & & \\
\hline Lemna valdiviana (duckweed) & $\mathrm{X}$ & & & & & & & \\
\hline Myriophyllum aquaticum (parrotfeather) & $\mathrm{X}$ & & & & & & & \\
\hline Myriophyllum spicatum (watermilfoil) & & $\mathrm{X}$ & & & & & & \\
\hline Nuphar luteum (spatterdock) & $\mathrm{X}$ & & & & & & & \\
\hline Pontederia cordata (pickerel weed) & $\mathrm{X}$ & & & & & & & \\
\hline Pistia stratiotes (water lettuce) & $\mathrm{X}$ & & & & & & & \\
\hline Syringodium filiforme (manatee grass) & & & $\mathrm{X}$ & $\mathrm{X}$ & $\mathrm{X}$ & $\mathrm{X}$ & $\mathrm{X}$ & \\
\hline Thalassia testudinum (turtle grass) & & & $\mathrm{X}$ & $\mathrm{X}$ & $\mathrm{X}$ & $\mathrm{X}$ & $\mathrm{X}$ & $\mathrm{X}$ \\
\hline Unknown grass & $\mathrm{X}$ & & & & & & & \\
\hline
\end{tabular}

Johns River were sampled repeatedly during different months to assess potential seasonal variability.

Skin samples from free-ranging manatees in Florida $(n=118)$, Belize $(n=68)$, and Puerto Rico $(n=23)$ were
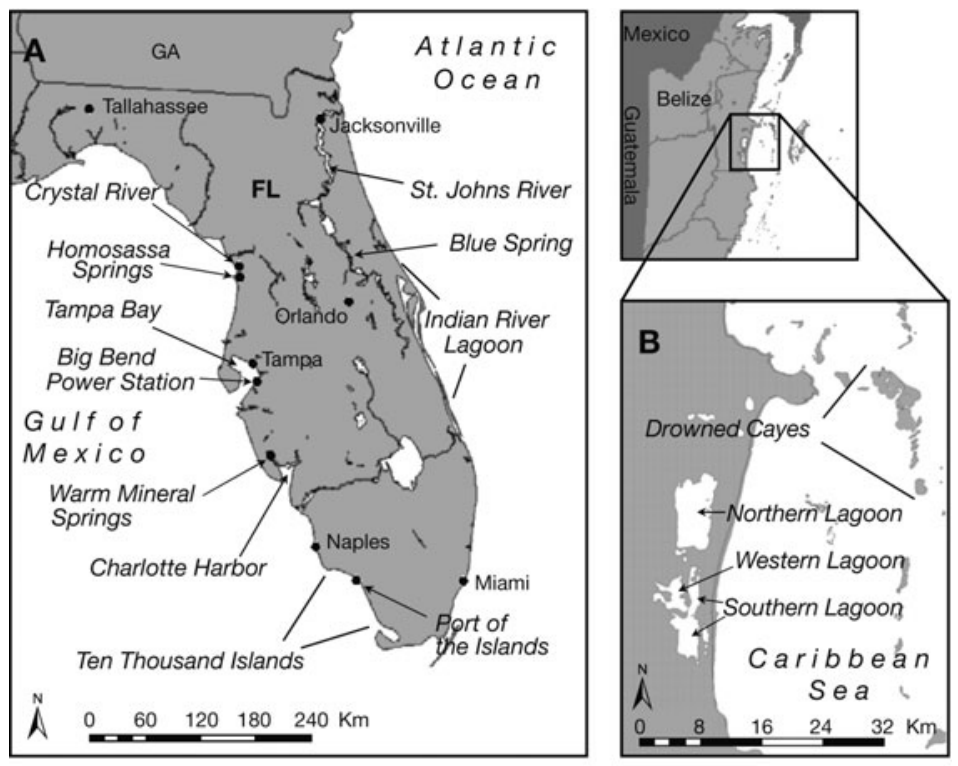

Fig. 1. Study areas in (A) Florida, (B) Belize, and (C) Puerto Rico collected during 2002 to 2005 as part of a larger study examining genetic relatedness. Sampling locations in Florida included Crystal River, Homosassa Springs, Tampa Bay (Big Bend Power Station, Tampa), Ten Thousand Islands (Port of the Islands, Naples), and Charlotte Harbor (Warm Mineral Springs; Fig. 1). Most Florida manatees ( $\mathrm{n}=$ 113) were sampled during the fall and winter months when they often congregate in large numbers at natural or artificial warm water sources. Sampling locations in Belize included the Northern Lagoon, Southern Lagoon, Western Lagoon (part of the Southern Lagoon), and Drowned Cayes (Fig. 1). Locations in Puerto Rico included Cabo Rojo, Ceiba, Guayanilla, and Salinas (Fig. 1). Samples from Antillean manatees in Belize and Puerto Rico were collected opportunistically over multiple years. For seasonal comparisons, winter was defined as December through February, spring as March through May, summer as June through August, and fall as September through November.

Epidermal tissue was collected from the edge of the paddle using a cattle ear notch tool. Sex was determined by observing the position of the urogenital slit, and standard body length was measured as the straight distance from snout to paddle. Florida manatees were categorized into 3 age classes based on body length measurements (adults: $>275 \mathrm{~cm}$; subadults/late juveniles: $176-275 \mathrm{~cm}$; and 
calves: $<176 \mathrm{~cm}$; O'Shea et al. 1985). Antillean manatees were also categorized into age classes, although these classes were defined by different body length measurements since Antillean manatees are slightly smaller (adults: $>225 \mathrm{~cm}$; subadults/late juveniles:

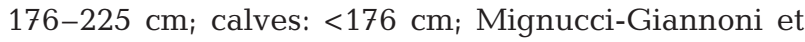
al. 2000).

Sample preparation and analysis. All manatee tissue and plant samples were frozen within $2 \mathrm{~h}$ of collection and held at $-20^{\circ} \mathrm{C}$ until time of analysis. Samples were then rinsed with distilled water and oven dried at $60^{\circ} \mathrm{C}$ for $24 \mathrm{~h}$. Lipids were removed using petroleum ether in a Soxhlet extractor for $24 \mathrm{~h}$ to remove the potential effect of lipids on $\delta^{13} \mathrm{C}$ values (Rau et al. 1992). Samples were then oven dried at $60^{\circ} \mathrm{C}$ for $24 \mathrm{~h}$ to remove any remaining solvent. Samples were ground and homogenized using a SPEX 8000 Mixer/ Mill (CertiPrep) or a Wig-L-Bug Amalgamator (Crescent Dental Manufacturing), or they were chopped by hand using a scalpel. Approximately $1.0 \mathrm{mg}$ of manatee tissue or $2.5 \mathrm{mg}$ of plant materials were transferred to $5 \times 9 \mathrm{~mm}$ tin capsules and analyzed for carbon and nitrogen stable isotope ratios by mass spectrometry (Thermo Finnigan DELTAplus and DELTA C) at the Stable Isotope and Ecology Lab, University of Georgia, Athens, GA. Seagrasses were analyzed with and without epiphytes when possible. Seagrasses analyzed with epiphytes were prepared as discussed previously for other aquatic plants, with the exception that they were rinsed in saltwater instead of distilled water to prevent further removal of epiphytes.

Data analysis. Stable isotope ratios were expressed in ppt (\%) using delta notation:

$$
\delta \mathrm{x}=\left(R_{\text {sample }} / R_{\text {standard }}-1\right) \times 1000
$$

in which $R_{\text {sample }}$ and $R_{\text {standard }}$ are the absolute isotope ratios of the sample and standard (bovine tissue), respectively, and $\mathrm{x}$ is ${ }^{13} \mathrm{C}$ or ${ }^{15} \mathrm{~N}$. Quality assurance of stable isotope ratios was tested by running 1 known standard sample for each 12 unknown (manatee or plant) samples. Analytical errors for the bovine tissue were $\pm 0.1 \mathrm{SD}$ for $\delta^{13} \mathrm{C}$ and $\delta^{15} \mathrm{~N}$.

Statistical analysis. All statistical analyses were judged to be significant at $p<0.05$. Data were tested for normality using the Shapiro-Wilk $(\mathrm{n}<50)$ and Kolmogorov-Smirnov $(\mathrm{n}>50)$ tests. Levene's $F$ and Box's $M$ were used to test homogeneity of variance between factors and homogeneity of covariance, respectively. Differences in $\delta^{13} \mathrm{C}$ and $\delta^{15} \mathrm{~N}$ values were tested using parametric and non-parametric analyses as appropriate. Differences in $\delta^{13} \mathrm{C}$ and $\delta^{15} \mathrm{~N}$ of manatee skin were tested using MANOVA with the following main and interaction effects: sex, age, season, location, sex and location, sex and age class, and sex and season. Data are presented as means $\pm \mathrm{SE}$.
Diet modeling. Recent developments in multiple source isotope mixing models allow for the calculation of relative proportions of different prey in the diet. IsoError version 1.04 is a Microsoft Excel ${ }^{\mathrm{TM}}$ worksheet that calculates proportions of source contributions to a mixture (including variances, standard errors, and confidence intervals) while accounting for variability in stable isotope signatures (see Phillips \& Gregg 2001 for a full description and discussion). Using this mixing model and published diet-tissue discrimination values (Alves-Stanley \& Worthy 2009), proportions of freshwater vegetation, estuarine vegetation, and seagrasses contributing to the Florida manatee diet were estimated.

\section{RESULTS}

\section{Diet analysis}

Florida aquatic plants

Because turtle grass Thalassia testudinum often has a large amount of epiphytic algae and other encrusting organisms attached to the blades, $\delta^{13} \mathrm{C}$ and $\delta^{15} \mathrm{~N}$ values for clean and epiphytic blades were initially compared. Paired $t$-tests indicated no significant difference in $\delta^{13} \mathrm{C}$ $(t=2.15, \mathrm{df}=10, \mathrm{p}=0.057)$ or $\delta^{15} \mathrm{~N}$ values $(t=1.13, \mathrm{df}=$ $10, \mathrm{p}=0.29$ ) between clean blades (mean $\delta^{13} \mathrm{C}=-11.9 \pm$ $0.8 \%$, mean $\delta^{15} \mathrm{~N}=2.1 \pm 0.4 \%$ ) and those with epiphytes present (mean $\delta^{13} \mathrm{C}=-12.9 \pm 0.8 \%$, mean $\delta^{15} \mathrm{~N}=2.4 \pm$ $0.5 \%$ ), so samples were grouped for further analyses.

Stable isotope signatures of aquatic vegetation were compared between collection locations in order to examine potential distinctions between freshwater plants, estuarine plants, and seagrasses. Welch analysis of variance (ANOVA) results indicated that $\delta^{13} \mathrm{C}$ values differed significantly $\left(F_{6,27}=189.27, \mathrm{p}<0.001\right)$. Freshwater plants were the most depleted in ${ }^{13} \mathrm{C}$, while seagrasses were the most enriched. Plants that had intermediate $\delta^{13} \mathrm{C}$ values, those collected from Crystal River and marine algae from the Indian River Lagoon, were categorized as estuarine vegetation (Table 2, Fig. 2). Regardless of collection location, $\delta^{13} \mathrm{C}$ values differed between all 3 plant types (Tamhane's T2: all p-values < 0.021). Welch ANOVA results also indicated that $\delta^{15} \mathrm{~N}$ values differed significantly between collection locations $\left(F_{6,34}=38.19, \mathrm{p}<0.001\right)$. Regardless of collection location, all seagrasses were significantly depleted in ${ }^{15} \mathrm{~N}$ compared to freshwater and estuarine vegetation (Tamhane's T2: all $\mathrm{p}$-values $<0.002$ ), but $\delta^{15} \mathrm{~N}$ values did not differ between freshwater and estuarine vegetation (all p-values $>0.61$, Table 2, Fig. 2).

Within seagrass samples, $\delta^{13} \mathrm{C}$ values differed significantly between collection locations (Welch ANOVA: $F_{3,27}=5.51, \mathrm{p}=0.004$ ) with seagrasses from Tampa Bay 
Table 2. Stable isotope ratios of aquatic plants collected in Florida and Belize

\begin{tabular}{|c|c|c|c|c|c|c|c|}
\hline \multirow[t]{2}{*}{ Plant type } & \multirow[t]{2}{*}{$\mathrm{n}$} & \multicolumn{3}{|c|}{$-\delta^{13} \mathrm{C}(\% \circ)$} & \multicolumn{3}{|c|}{$-\delta^{15} \mathrm{~N}(\%)-$} \\
\hline & & Mean \pm SE & Minimum & Maximum & Mean \pm SE & Minimum & Maximum \\
\hline \multicolumn{8}{|l|}{ Florida } \\
\hline \multicolumn{8}{|l|}{ Freshwater vegetation } \\
\hline St. Johns River & 29 & $-28.1 \pm 0.3$ & -31.6 & -25.0 & $7.3 \pm 0.5$ & 1.9 & 10.3 \\
\hline Estuarine vegetation & 13 & $-22.1 \pm 0.6$ & -25.1 & -18.8 & $6.3 \pm 0.2$ & 5.4 & 7.6 \\
\hline Crystal River & 5 & $-22.3 \pm 0.8$ & -24.2 & -20.1 & $6.0 \pm 0.3$ & 5.4 & 7.1 \\
\hline Indian River Lagoon & 8 & $-21.9 \pm 0.9$ & -25.1 & -18.8 & $6.4 \pm 0.3$ & 5.5 & 7.6 \\
\hline Seagrasses & 59 & $-13.1 \pm 0.4$ & -19.6 & -6.6 & $1.6 \pm 0.3$ & -2.9 & 5.4 \\
\hline Charlotte Harbor & 15 & $-11.0 \pm 0.5$ & -15.5 & -8.3 & $1.4 \pm 0.3$ & -0.7 & 4.4 \\
\hline Indian River Lagoon & 13 & $-13.8 \pm 1.2$ & -19.6 & -6.6 & $1.1 \pm 0.7$ & -2.0 & 5.3 \\
\hline Tampa Bay & 16 & $-14.8 \pm 0.8$ & -19.5 & -9.2 & $2.5 \pm 0.4$ & 0.2 & 5.4 \\
\hline Ten Thousand Islands & 15 & $-12.9 \pm 0.5$ & -16.9 & -9.5 & $1.1 \pm 0.6$ & -2.9 & 3.8 \\
\hline \multicolumn{8}{|l|}{ Belize } \\
\hline \multicolumn{8}{|l|}{ Seagrasses } \\
\hline Drowned Cayes & 18 & $-7.2 \pm 0.5$ & -11.9 & -2.9 & $-0.6 \pm 0.5$ & -5.1 & 2.6 \\
\hline
\end{tabular}
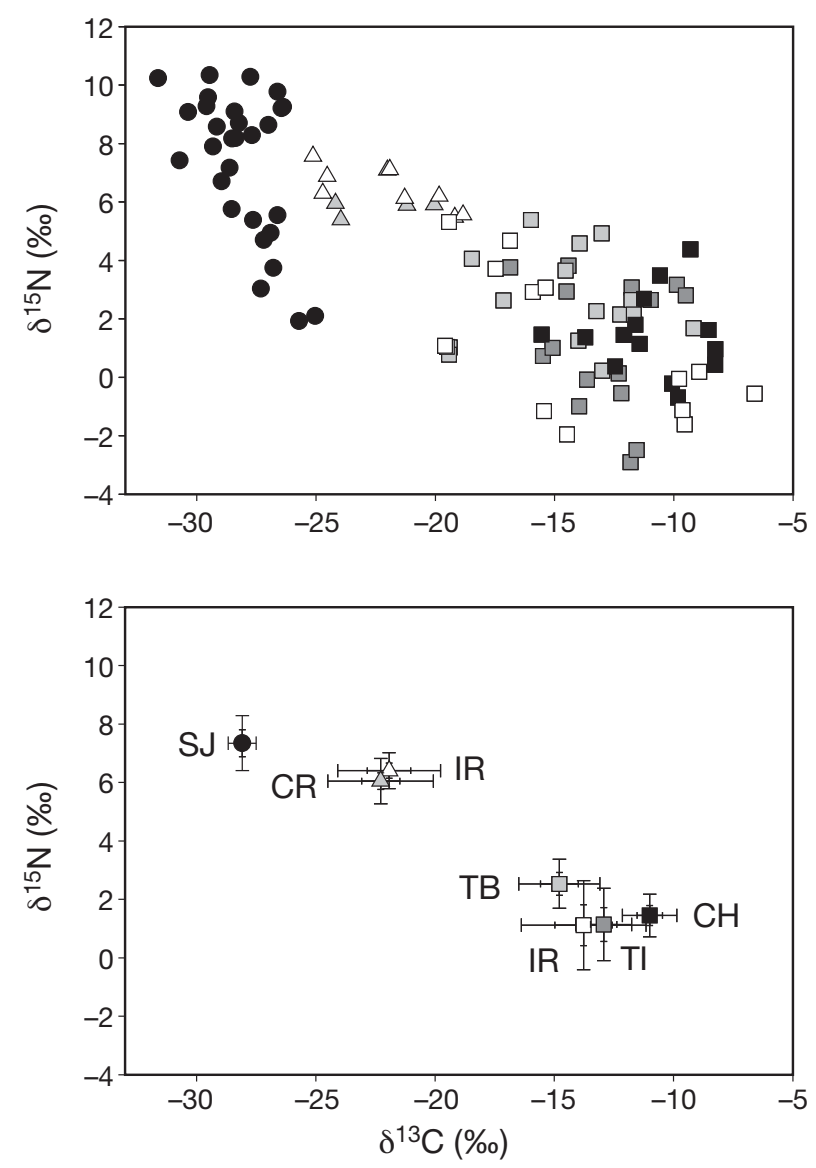

Fig. 2. Stable isotope values (scatterplot and mean \pm SE and $95 \%$ CI) for aquatic plants in Florida. Circles represent freshwater vegetation, triangles represent estuarine vegetation, and squares represent seagrasses. Location abbreviations as in Table 1 being significantly depleted in ${ }^{13} \mathrm{C}$ by an average of $3.8 \%$ compared to those from Charlotte Harbor (Tamhane's T2: $\mathrm{p}=0.003$, Table 2, Fig. 2). No other significant differences were calculated for $\delta^{13} \mathrm{C}$ values between any other collection locations (Tamhane's T2: all p-values $>0.26) . \delta^{13} \mathrm{C}$ values did not differ between seagrass species regardless of how locations were grouped (ANOVA: $F<1.1$, all p-values $>0.37$ ). Finally, $\delta^{15} \mathrm{~N}$ values for seagrasses did not differ between collection locations (Welch ANOVA: $F_{3,26}=1.79, \mathrm{p}=0.17$, Table 2, Fig. 2) or species (ANOVA: $F_{2,53}=2.34, \mathrm{p}=$ 0.11). Star grass Halophila engelmannii was collected at only 1 location (Ten Thousand Islands), preventing inclusion in this analysis.

Freshwater plants from St. Johns River were collected during the months of April, July, and December, allowing for a seasonal comparison. Main effects for month and plant species were tested using multivariate ANOVA (MANOVA). There was a significant effect of month (Wilks' lambda: $F_{4,28}=4.22, \mathrm{p}=0.009$ ), but there was no effect of species $\left(F_{16,28}=1.63, \mathrm{p}=0.13\right)$. The $\delta^{13} \mathrm{C}$ values of freshwater plants did not differ between months (ANOVA: $F_{2,23}=2.83, \mathrm{p}=0.080$ ), but $\delta^{15} \mathrm{~N}$ values were significantly different $\left(F_{2,23}=12.73, \mathrm{p}<0.001\right)$. Plants collected in July were depleted in ${ }^{15} \mathrm{~N}$ by an average of $3.9 \%$ compared to those collected in December and April (both p-values < 0.002, Tukey HSD).

\section{Belize aquatic plants}

Samples of turtle grass Thalassia testudinum and shoal grass Halodule wrightii were collected opportunistically from the Drowned Cayes in Belize (Fig. 1). 
Table 3. Stable isotope ratios in manatee skin from free-ranging animals in Florida, Belize, and Puerto Rico

\begin{tabular}{|c|c|c|c|c|c|c|c|}
\hline \multirow[t]{2}{*}{ Location } & \multirow[t]{2}{*}{$\mathrm{n}$} & \multicolumn{3}{|c|}{$-\delta^{13} \mathrm{C}(\%)-$} & \multicolumn{3}{|c|}{$\longrightarrow \delta^{15} \mathrm{~N}(\% \mathrm{o})-$} \\
\hline & & Mean \pm SE & Minimum & Maximum & Mean $\pm \mathrm{SE}$ & Minimum & Maximum \\
\hline \multicolumn{8}{|l|}{ Florida } \\
\hline Riverine manatees & 88 & $-20.4 \pm 0.3$ & -27.0 & -14.6 & $7.0 \pm 0.1$ & 2.7 & 10.1 \\
\hline Crystal River (CR) & 67 & $-20.0 \pm 0.3$ & -24.9 & -14.6 & $7.1 \pm 0.2$ & 3.8 & 10.1 \\
\hline Homosassa Springs (HS) & 21 & $-21.4 \pm 0.6$ & -27.0 & -16.3 & $6.5 \pm 0.3$ & 2.7 & 9.2 \\
\hline Coastal manatees & 30 & $-14.2 \pm 0.5$ & -20.4 & -9.3 & $4.6 \pm 0.3$ & 2.0 & 8.1 \\
\hline Big Bend Power Station (BP) & 10 & $-13.5 \pm 0.5$ & -15.4 & -10.9 & $5.8 \pm 0.6$ & 2.0 & 8.1 \\
\hline Port of the Islands (PI) & 14 & $-13.8 \pm 0.7$ & -17.6 & -9.3 & $4.0 \pm 0.2$ & 3.0 & 6.2 \\
\hline Warm Mineral Springs (WS) & 6 & $-16.3 \pm 1.2$ & -20.4 & -13.1 & $4.0 \pm 0.5$ & 2.8 & 5.6 \\
\hline \multicolumn{8}{|l|}{ Belize } \\
\hline Drowned Cayes (DC) & 13 & $-7.5 \pm 0.4$ & -11.0 & -5.9 & $3.4 \pm 0.2$ & 2.1 & 4.7 \\
\hline All lagoons & 55 & $-12.7 \pm 0.2$ & -16.0 & -9.2 & $1.6 \pm 0.3$ & -2.3 & 5.7 \\
\hline Northern Lagoon (NL) & 8 & $-13.4 \pm 0.4$ & -15.5 & -12.4 & $4.1 \pm 0.3$ & 2.6 & 5.3 \\
\hline Southern Lagoon (SL) & 37 & $-12.4 \pm 0.3$ & -16.0 & -9.2 & $1.0 \pm 0.3$ & -2.3 & 5.7 \\
\hline Western Lagoon (WL) & 10 & $-13.3 \pm 0.4$ & -15.1 & -11.5 & $1.5 \pm 0.7$ & -2.3 & 4.1 \\
\hline \multicolumn{8}{|l|}{ Puerto Rico } \\
\hline Cabo Rojo (CA) & 7 & $-9.6 \pm 0.5$ & -10.9 & -7.9 & $4.9 \pm 0.2$ & 3.7 & 5.7 \\
\hline Ceiba (CE) & 6 & $-10.1 \pm 0.6$ & -12.8 & -8.8 & $4.6 \pm 0.3$ & 3.8 & 5.4 \\
\hline Guayanilla (GU) & 9 & $-9.6 \pm 0.4$ & -11.0 & -7.5 & $6.2 \pm 0.2$ & 5.2 & 6.9 \\
\hline Salinas (SA) & 1 & -10.4 & -10.4 & -10.4 & 5.7 & 5.7 & 5.7 \\
\hline
\end{tabular}

The $\delta^{13} \mathrm{C}$ values ranged from -11.9 to $-2.9 \%$ and $\delta^{15} \mathrm{~N}$ values ranged from -5.1 to $2.6 \%$ (Table 2). Species comparisons were not undertaken due to small sample size, but $\delta^{13} \mathrm{C}$ and $\delta^{15} \mathrm{~N}$ values for $H$. wrightii fell within the range of those of $T$. testudinum (Table 2). There was no effect of collection month (July-September, MANOVA: Wilks' lambda: $F_{4,28}=0.97, \mathrm{p}=0.44$ ) between seagrasses in Belize.

\section{Free-ranging manatees}

Florida manatees

The $\delta^{13} \mathrm{C}$ values for manatee skin increased from very depleted signatures for skin collected in freshwater regions to more enriched signatures for skin collected in coastal regions. The $\delta^{15} \mathrm{~N}$ values for manatee skin decreased from enriched signatures for skin collected in freshwater regions to depleted signatures for skin collected in coastal regions (Table 3, Fig. 3).

MANOVA was run for $\delta^{13} \mathrm{C}$ and $\delta^{15} \mathrm{~N}$ values using the following main and interaction effects: sex, age class, location, sex and age class, and sex and location. No significant effects were noted for sex $\left(F\right.$ test: $F_{2,99}=$ $0.28, \mathrm{p}=0.76$ ), age class (Wilks' lambda: $F_{4,198}=0.76$, $\mathrm{p}=0.55)$, or either of the interaction effects $(F<0.66$, both $p$-values $>0.73$ ), but there was a significant effect for location (Wilks' lambda: $F_{8,198}=13.49, \mathrm{p}<0.001$ ).

Both $\delta^{13} \mathrm{C}$ (ANOVA: $F_{4,113}=43.39, \mathrm{p}<0.001$ ) and $\delta^{15} \mathrm{~N}$ values $\left(F_{4,113}=20.15, \mathrm{p}<0.001\right)$ for manatee skin differed significantly based on location. Skin from
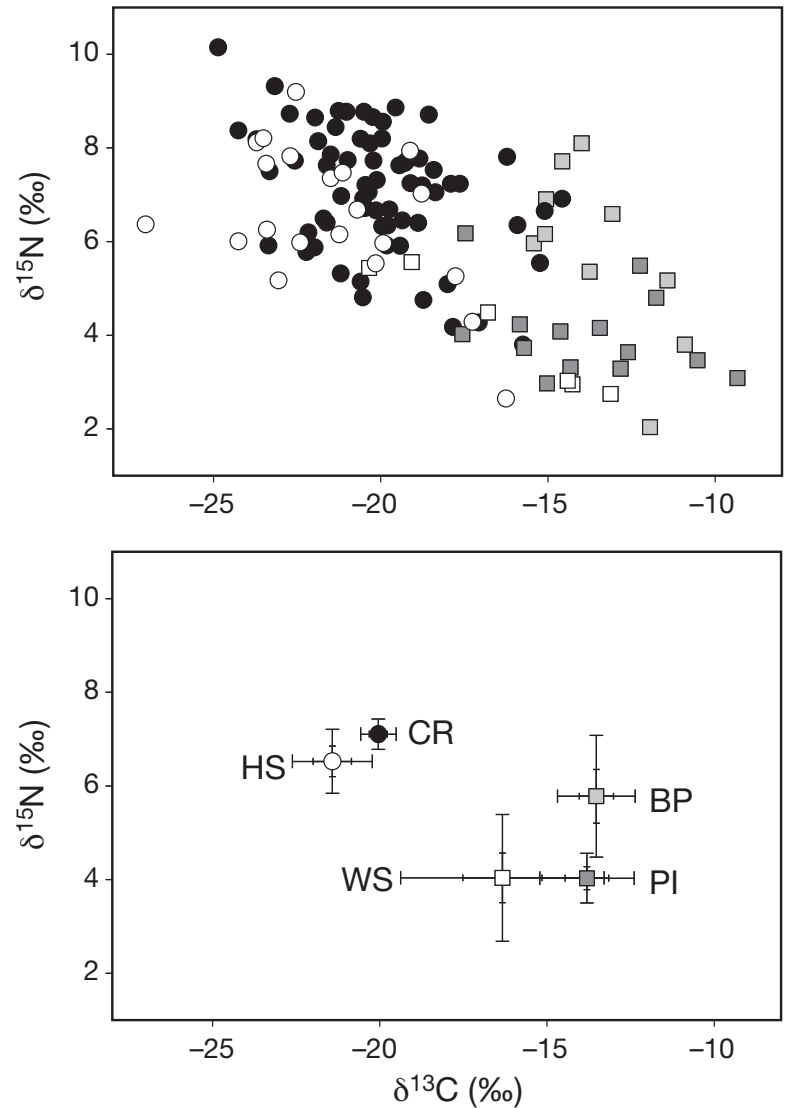

Fig. 3. Trichechus manatus latirostris. Stable isotope values (scatterplot and mean $\pm \mathrm{SE}$ and $95 \% \mathrm{CI}$ ) for manatee skin collected from animals in Florida. Circles represent riverine manatees and squares represent coastal manatees. Location abbreviations as in Table 3 
manatees sampled in Crystal River and Homosassa Springs was depleted in ${ }^{13} \mathrm{C}$ by an average of $6.2 \%$ compared to skin from manatees at the Big Bend Power Plant, Port of the Islands, and Warm Mineral Springs (Tukey HSD: all p-values < 0.010, Table 3, Fig. 3). The $\delta^{15} \mathrm{~N}$ values differed significantly between skin from manatees at the Big Bend Power Plant and Port of the Islands by an average of $1.8 \%$ (Tukey HSD: $\mathrm{p}=0.020$, Table 3, Fig. 3). The $\delta^{15} \mathrm{~N}$ values did not significantly differ between skin from manatees at any other locations (Tukey HSD: all p-values > 0.10). Because there were no significant differences in $\delta^{13} \mathrm{C}$ or $\delta^{15} \mathrm{~N}$ values in skin from manatees sampled in Crystal River and Homosassa Springs, data from these 2 Florida locations were pooled ('riverine manatees') for further analyses (Table 3, Fig. 3). In addition, because there were no significant differences in $\delta^{13} \mathrm{C}$ values in skin from manatees at the Big Bend Power Plant, Port of the Islands, and Warm Mineral Springs, data from these 3 Florida locations were pooled ('coastal manatees') for further analyses.

Age class comparisons were further investigated since sample distribution did not allow testing for an interaction effect between age class and location. Within riverine manatees, all skin samples were from calves or subadults. MANOVA showed no effect for age class ( $F$ test: $\left.F_{2,85}=0.09, \mathrm{p}=0.91\right)$. For skin from coastal manatees, $\delta^{13} \mathrm{C}$ values did not differ between any of the 3 age classes (ANOVA: $F_{2,27}=3.27, \mathrm{p}=$ 0.054). Regardless of how locations were grouped for coastal manatees, $\delta^{15} \mathrm{~N}$ values of skin also did not differ between age classes (all test statistics $<1.9$, all p-values > 0.082).

Month of skin sample collection was further investigated as a possible effect on carbon and nitrogen stable isotope ratios. For skin from riverine manatees, MANOVA failed to show an effect for month (October to February, Wilks' lambda: $F_{8,160}=0.72, \mathrm{p}=0.67$ ). For skin from coastal manatees, $\delta^{13} \mathrm{C}$ values did not differ between months (January, December, and April, ANOVA: $\left.F_{2,27}=1.57, \mathrm{p}=0.23\right)$. The $\delta^{15} \mathrm{~N}$ values of skin also did not differ between months, regardless of how the locations were grouped for coastal manatees $(F<$ 0.2 , all $p$-values $>0.82$ ).

\section{Antillean manatees (Belize)}

The $\delta^{13} \mathrm{C}$ values for Antillean manatee skin ranged from depleted for skin collected from lagoon regions to more enriched for skin collected from the Drowned Cayes (Table 3, Fig. 4). Differences in $\delta^{13} \mathrm{C}$ values were tested using ANOVA with the following main and interaction effects: sex, age class, season, location, sex and location, sex and season, and age class and season.
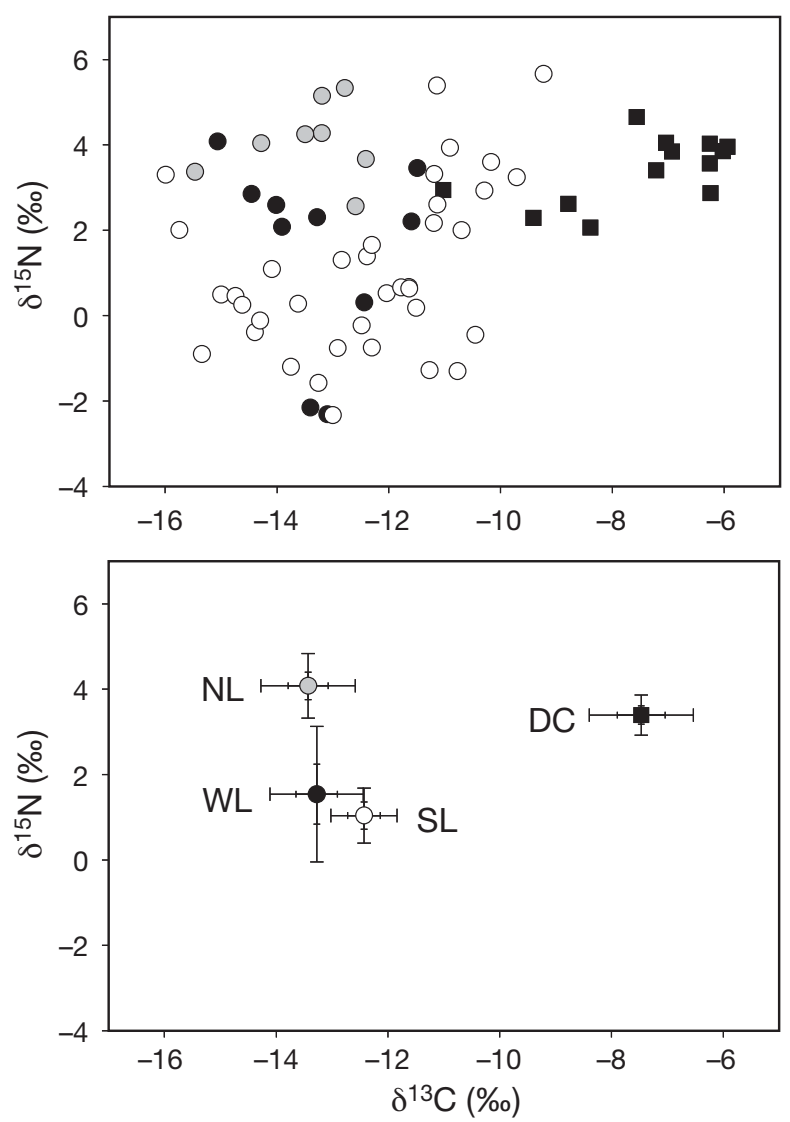

Fig. 4. Trichechus manatus manatus. Stable isotope values (scatterplot and mean \pm SE and 95\% CI) for manatee skin collected from animals in Belize. Circles represent lagoon manatees and squares represent manatees from the Drowned Cayes. Location abbreviations as in Table 3

There were significant effects for location $\left(F_{3,71}=\right.$ $21.41, \mathrm{p}<0.001)$ and season $\left(F\right.$ test: $F_{2,71}=3.77, \mathrm{p}=$ $0.028)$, but no other effects were significant $(F<2.00$, all p-values $>0.13$ ).

Skin from manatees sampled in the Drowned Cayes was significantly enriched in ${ }^{13} \mathrm{C}$ by an average of $5.2 \%$ compared to samples from the 3 lagoons (Tukey HSD: all p-values $<0.001$, Table 3, Fig. 4), but there were no differences in $\delta^{13} \mathrm{C}$ values between lagoon samples (all $\mathrm{p}$-values $>0.37$ ). The $\delta^{15} \mathrm{~N}$ values also differed significantly between manatee skin from different locations (Welch ANOVA: $F_{3,22}=17.86, \mathrm{p}<0.001$ ). There was a difference in $\delta^{15} \mathrm{~N}$ values between manatees sampled in the Drowned Cayes and Southern Lagoon (Tamhane's T2: $\mathrm{p}<0.001$ ). Additionally, $\delta^{15} \mathrm{~N}$ values for skin samples from the Northern Lagoon differed significantly from those of the Southern $(p<$ 0.001) and Western Lagoons ( $p=0.036$, Table 3, Fig. 4).

Samples in Belize were collected during fall and spring (rainy and dry seasons, respectively). Results of $t$-tests indicated that manatee skin collected in the spring was 
significantly enriched in both ${ }^{13} \mathrm{C}$ (Drowned Cayes, $t=$ 5.18, $\mathrm{df}=11, \mathrm{p}<0.001$; Southern Lagoon, $t=2.95, \mathrm{df}=35$, $\mathrm{p}=0.006$ ) and ${ }^{15} \mathrm{~N}$ (Drowned Cayes, $t=2.32, \mathrm{df}=11, \mathrm{p}=$ 0.041; Southern Lagoon, $t=2.41, \mathrm{df}=33, \mathrm{p}=0.022$ ) compared to skin collected in the fall. There was no seasonal difference in $\delta^{13} \mathrm{C}$ values for manatee skin collected in the Western Lagoon ( $t=0.50, \mathrm{df}=8, \mathrm{p}=0.63)$, but skin collected in the spring was significantly depleted in ${ }^{15} \mathrm{~N}$ compared to that collected in the fall $(t=6.22, \mathrm{df}=8, \mathrm{p}<$ 0.001). Manatees from the Northern Lagoon were sampled exclusively during the spring.

\section{Antillean manatees (Puerto Rico)}

$\delta^{13} \mathrm{C}$ values for manatee skin ranged from $-12.8 \%$ for an animal from Ceiba to $-7.5 \%$ o for an animal from Guayanilla. $\delta^{15} \mathrm{~N}$ values ranged from $3.7 \%$ for an animal from Cabo Rojo to $6.9 \%$ for an animal from Guayanilla (Table 3, Fig. 5).

There was a significant effect of location ( $F$ test: $\left.F_{2,11}=4.22, \mathrm{p}=0.043\right)$, but no other effects were signif-
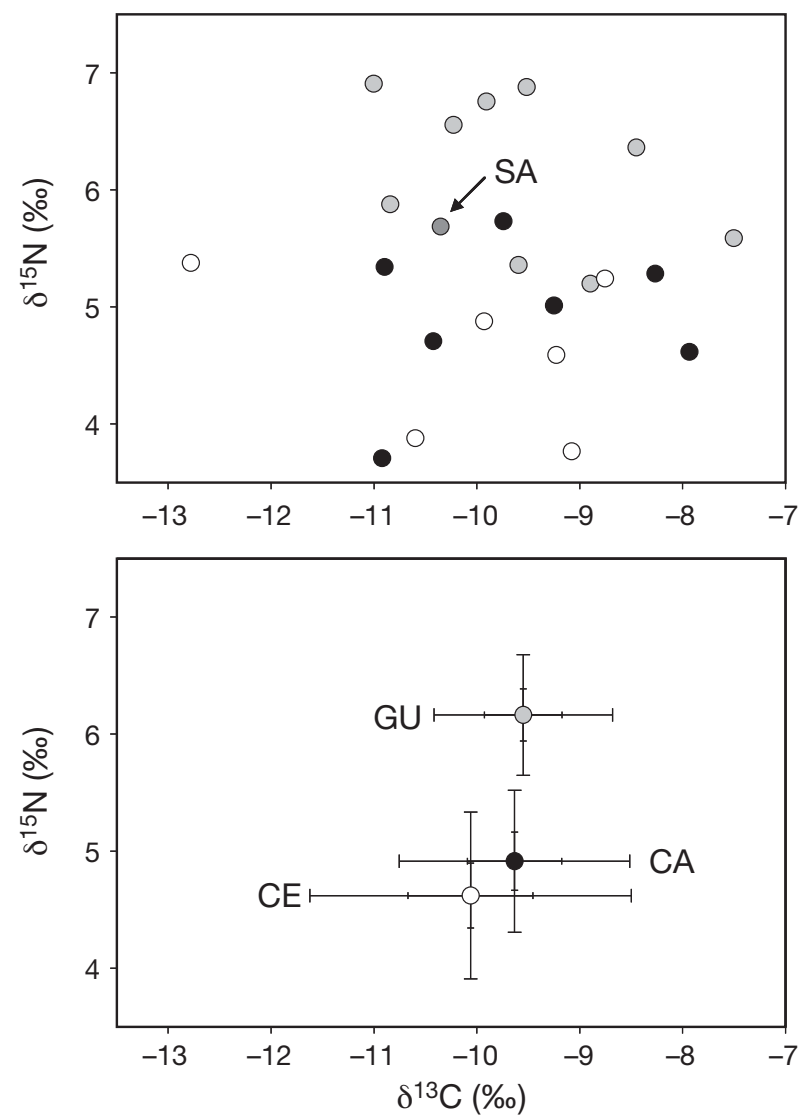

Fig. 5. Trichechus manatus manatus. Stable isotope values (scatterplot and mean \pm SE and $95 \%$ CI) for manatee skin collected from animals in Puerto Rico. Location abbreviations as in Table 3 icant $(F<2.60$, all p-values $>0.11)$. Only 1 skin sample was analyzed from Salinas, so it was not included in these analyses. There were no significant differences in $\delta^{13} \mathrm{C}$ values (ANOVA: $F_{2,19}=0.32, \mathrm{p}=0.73$ ) between the 3 locations (Guayanilla, Cabo Rojo, and Ceiba), but there was a significant difference in $\delta^{15} \mathrm{~N}$ values $\left(F_{2,19}=\right.$ 11.76, p < 0.001). Samples from Guayanilla were enriched in ${ }^{15} \mathrm{~N}$ by an average of $1.4 \%$ compared to those from both Cabo Rojo and Ceiba (Tukey HSD: both p-values <0.01, Table 3, Fig. 5).

\section{Diet modeling}

Carbon and nitrogen signatures for freshwater, estuarine, and marine vegetation (seagrasses) were plotted with a polygon connecting their mean values as possible diet sources for manatees in Florida (Fig. 6). The diet source mean values for $\delta^{13} \mathrm{C}$ were corrected for diet-tissue discrimination by $2.8 \%$ as measured by Alves-Stanley \& Worthy (2009) and consistent with Reich \& Worthy (2006). To fit the isotopic signature of the consumer within the diet source polygon, possible nitrogen diet-tissue discrimination values ranging from 1.0 to $1.5 \%$ o were used.

IsoError analysis suggested that freshwater and/or estuarine vegetation was the main diet component for Florida riverine manatees, while seagrasses were the main diet component for coastal manatees regardless of the nitrogen diet-tissue discrimination value (Table 4). IsoError results are especially sensitive to

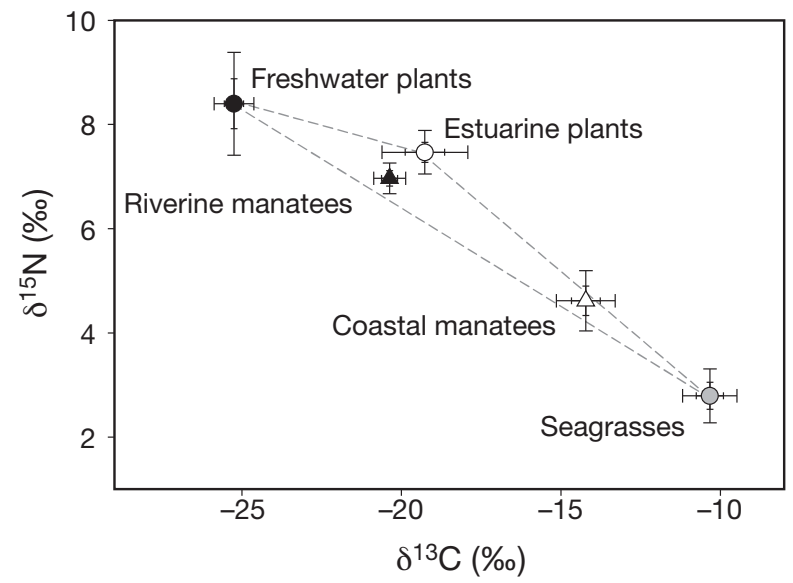

Fig. 6. Trichechus manatus latirostris. Estimation of diettissue discrimination in the skin of free-ranging Florida manatees. $\delta^{13} \mathrm{C}$ and $\delta^{15} \mathrm{~N}$ values (mean $\pm \mathrm{SE}$ and $95 \% \mathrm{CI}$ ) for aquatic vegetation and manatee skin were compared, and the 3 possible diet sources (corrected for diet-tissue discrimination) were connected by a polygon. The accepted enrichment values for manatee skin necessary for the means to fall within the polygon were $2.8 \%$ for carbon and ranged from 1.0 to $1.5 \%$ for nitrogen $(1.2 \%$ was plotted) 
Table 4. IsoError results representing possible proportions of freshwater vegetation, estuarine vegetation, and seagrasses contributing to the manatee diet. Diet source means were corrected for diet-tissue discrimination by $2.8 \%$ for carbon. Model criteria allowed diet-tissue discrimination (enrichment) factors for nitrogen ranging from 1.0 to $1.5 \%$, so 3 possible solutions are shown for riverine and coastal manatees

\begin{tabular}{|c|c|c|c|c|c|c|c|c|c|}
\hline \multirow[t]{2}{*}{ Diet source } & \multicolumn{3}{|c|}{$\delta^{15} \mathrm{~N}$ enrichment $=1.0 \%$} & \multicolumn{3}{|c|}{$\delta^{15} \mathrm{~N}$ enrichment $=1.2 \%$} & \multicolumn{3}{|c|}{$\delta^{15} \mathrm{~N}$ enrichment $=1.5 \%$} \\
\hline & $\begin{array}{c}\text { Mean } \pm \text { SE } \\
(\%)\end{array}$ & $\begin{array}{l}\text { Lower } \\
95 \% \text { CI }\end{array}$ & $\begin{array}{c}\text { Upper } \\
95 \% \text { CI }\end{array}$ & $\begin{array}{c}\text { Mean } \pm \text { SE } \\
(\%)\end{array}$ & $\begin{array}{l}\text { Lower } \\
95 \% \text { CI }\end{array}$ & $\begin{array}{l}\text { Upper } \\
95 \% \text { CI }\end{array}$ & $\begin{array}{c}\text { Mean } \pm \text { SE } \\
(\%)\end{array}$ & $\begin{array}{l}\text { Lower } \\
95 \% \text { CI }\end{array}$ & $\begin{array}{l}\text { Upper } \\
95 \% \text { CI }\end{array}$ \\
\hline \multicolumn{10}{|l|}{ Riverine manatees } \\
\hline Freshwater vegetation & $41 \pm 12$ & 16 & 66 & $50 \pm 13$ & 24 & 76 & $64 \pm 15$ & 34 & 95 \\
\hline Estuarine vegetation & $44 \pm 19$ & 5 & 82 & $28 \pm 21$ & 0 & 70 & $5 \pm 25$ & 0 & 55 \\
\hline Seagrasses & $15 \pm 8$ & 0 & 30 & $21 \pm 8$ & 4 & 38 & $31 \pm 10$ & 10 & 51 \\
\hline \multicolumn{10}{|l|}{ Coastal manatees } \\
\hline Freshwater vegetation & $2 \pm 17$ & 0 & 36 & $11 \pm 17$ & 0 & 45 & $25 \pm 18$ & 0 & 61 \\
\hline Estuarine vegetation & $40 \pm 26$ & 0 & 92 & $25 \pm 26$ & 0 & 77 & $1 \pm 28$ & 0 & 57 \\
\hline Seagrasses & $58 \pm 10$ & 39 & 77 & $64 \pm 10$ & 44 & 84 & $73 \pm 11$ & 52 & 95 \\
\hline
\end{tabular}

this diet-tissue discrimination value (or enrichment). When nitrogen enrichment was set to $1.0 \%$, the confidence interval of the model indicated that riverine manatees may not have had any seagrass component in their diet (lower 95\% CI = 0). IsoError results for coastal manatees did not require any freshwater or estuarine component to the diet regardless of the assumed nitrogen diet-tissue discrimination value (lower $95 \% \mathrm{CI}=0$ ).

\section{DISCUSSION}

\section{Diet analysis}

For aquatic plants collected in Florida and Belize, seagrasses were the most enriched in ${ }^{13} \mathrm{C}$, while freshwater plants were the most depleted, and estuarine plants had intermediate values. This pattern is consistent with findings in previous studies (e.g. Reich \& Worthy 2006, Alves-Stanley \& Worthy 2009). Aquatic plants incorporate carbon from the dissolved inorganic carbon (DIC) in the surrounding water into their tissues. DIC in freshwater is depleted in ${ }^{13} \mathrm{C}$ compared to that of seawater due to the isotope discrimination that takes place upon the conversion of $\mathrm{CO}_{2}$ into bicarbonate and the contribution of decomposing terrestrial matter (Boutton 1991). Freshwater and estuarine plants collected in Florida did not differ in their nitrogen signatures, but both plant types were significantly enriched in ${ }^{15} \mathrm{~N}$ compared to seagrasses. Differences in nitrogen ratios have been shown to be based on nitrogen source, specifically in freshwater versus marine ecosystems (e.g. Bardonnet \& Riera 2005); however, the understanding of nitrogen isotope patterns especially in aquatic plants is limited compared to those of carbon isotopes. The combined use of carbon and nitrogen stable isotope analysis further distinguishes the 3 aquatic plant types in this study.

No significant differences were found in $\delta^{13} \mathrm{C}$ or $\delta^{15} \mathrm{~N}$ values between Thalassia testudinum blades with or without epiphytes. Previous studies have shown conflicting results, in which some did find differences between isotope ratios in seagrasses versus epiphytes (e.g. Moncreiff \& Sullivan 2001) while others did not (e.g. Fry et al. 1982). Typically, epiphytes are depleted in ${ }^{13} \mathrm{C}$ and enriched in ${ }^{15} \mathrm{~N}$ compared to the seagrass blades from which they were removed. In terms of diet estimation, it is not likely that epiphyte signatures could cause seagrasses to be confused with signatures of freshwater plants. However, it is possible that the presence of epiphytes could cause carbon and nitrogen signatures of seagrasses to be more similar to those of estuarine vegetation.

Carbon and nitrogen stable isotope analyses were not precise enough to distinguish between aquatic plant species, but regional and seasonal differences in stable isotope ratios were found in Florida. Specifically, seagrasses collected from Charlotte Harbor were significantly enriched in ${ }^{13} \mathrm{C}$ compared to those from Tampa Bay. Variability in $\delta^{13} \mathrm{C}$ values in seagrasses is mainly an effect of carbon source but can also vary with irradiance and temperature (Hemminga \& Mateo 1996). Additionally, both carbon and nitrogen stable isotope ratios of seagrasses have been shown to exhibit seasonal and intra-annual variability (Anderson \& Fourqurean 2003, Vizzini et al. 2003). Seagrasses from Charlotte Harbor were collected in late spring and those from Tampa Bay were collected during the summer. It is unknown whether differences in $\delta^{13} \mathrm{C}$ between the 2 sites were due to location or a seasonal effect. In the St. Johns River, aquatic plants collected in July were significantly depleted in ${ }^{15} \mathrm{~N}$ compared to those collected in December and April. Differences in 
nitrogen signatures in plants may be due to seasonal variation in the amount of fertilizer runoff, wastewater discharge, and/or animal waste runoff into the aquatic system (Vizzini \& Mazzola 2006). Additionally, seasonal differences in water temperature, streamflow, and dissolved oxygen concentrations have been shown to affect nitrogen balance in the St. Johns River (Kroening 2004). Temporal and geographical variability in stable isotope ratios for aquatic plants should be taken into consideration when estimating diet proportions for consumers.

\section{Diet modeling}

Reliance on stable isotope mixing model results to estimate short-term manatee diet and/or habitat use through analysis of epidermal tissue is problematic due to slow turnover rates in the skin. Alves-Stanley \& Worthy (2009) calculated a mean half-life for ${ }^{13} \mathrm{C}$ turnover of $53 \mathrm{~d}$, while mean half-life for ${ }^{15} \mathrm{~N}$ turnover ranged from 65 to 72 d. Free-ranging manatees are known to switch diet sources (Best 1981, Lefebvre et al. 2000), and it is likely that as a result of these long turnover times, an intermediate isotope signature may be measured rather than one strictly representing a more recent diet. Rather than attempting to predict manatee diet composition involving all 3 aquatic plant types, it was thought to be more useful and more accurate to focus on the use of freshwater plants versus seagrasses. These vegetation types had very distinct $\delta^{13} \mathrm{C}$ and $\delta^{15} \mathrm{~N}$ values, whereas the $\delta^{15} \mathrm{~N}$ values for estuarine plants did not differ from those of freshwater plants. Also, the slow turnover rate in epidermal tissue makes this analysis a better representation of average overall dietary intake over a long period of time rather than an indication of recent intake. Finally, when interpreting mixing model results, upper and lower 95\% CI should be considered in addition to the mean values as a complete representation of possible diet source proportions (Phillips \& Gregg 2003).

Seagrasses were the most frequently 'required' component present in the diets of Florida manatees. Due to slow turnover rates, seagrasses were not necessarily a recent diet component, but all Florida manatees in the present study likely fed on seagrasses sometime in the months prior to sampling. Seagrasses were an even more critical component in the diet of manatees sampled at the Big Bend Power Plant, Port of the Islands, and Warm Mineral Springs. For manatees from these locations, it was conceivable that they had consumed no freshwater vegetation in recent months. Manatees from Crystal River and Homosassa Springs had a more varied reliance on plant types, with freshwater vegetation most often being the main component.
Reich \& Worthy (2006) used IsoError to estimate diet source proportions using skin from stranded manatee carcasses, but comparisons between the present study and their results may not be appropriate. diet-tissue discrimination values used for carbon were consistent (2.8\%, present study; $3.0 \%$, Reich \& Worthy 2006), but those for nitrogen were not (1.0 to $1.5 \%$, present study; $5.0 \%$, Reich \& Worthy 2006). Computing an accurate diet-tissue discrimination value is essential when using mixing models to estimate proportions of a multiple source diet (Phillips \& Koch 2002). Generally $\delta^{15} \mathrm{~N}$ diet-tissue discrimination values for whole body samples average 3\%o (Deniro \& Epstein 1981, Minagawa \& Wada 1984, Peterson \& Fry 1987). Most individual tissues are enriched in ${ }^{15} \mathrm{~N}$ by 2 to $5 \%$ compared to the diet (Peterson \& Fry 1987, Kelly 2000), yet values ranging from $<1$ to $6 \%$ have been calculated for individual mammalian tissues (Vanderklift \& Ponsard 2003). Hobson et al. (1996) calculated the only known diet-tissue discrimination value for nitrogen $(2.3 \%$ ) for the skin of marine mammals (phocid seals). Further captive studies are needed to determine an accurate diet-tissue discrimination value for nitrogen in manatee skin and thus improve the accuracy of diet source estimation.

Another difference is that Reich \& Worthy (2006) grouped manatees by much larger geographical regions. For example, the entire northwest Florida coast was grouped (including Tampa Bay). In the present study, manatees sampled in Crystal River and Homosassa Springs (northwest Florida) were grouped separately from those sampled at the Big Bend Power Plant (Tampa Bay) because stable carbon and nitrogen isotope ratios were significantly different in the skin. Consequently, it is likely too much of a generalization to categorize manatee feeding across larger geographical regions. Finally, it should be noted that no study involving manatee stable isotope analysis has used a concentration-dependent model such as that of Phillips \& Koch (2002), which may further refine results.

\section{Free-ranging manatees}

Although the lack of freshwater and estuarine plant samples prevented mixing model analysis for Antillean manatees, general comparisons and interpretations were made based on known patterns. Skin from manatees sampled in the Drowned Cayes in Belize was enriched in ${ }^{13} \mathrm{C}$ compared to that of lagoon manatees, consistent with a coastal diet of predominantly seagrasses, while the lagoon animals probably relied more heavily on estuarine and/or freshwater vegetation. There were no differences in carbon signatures among manatees from the 3 lagoons. However, skin 
from Northern Lagoon manatees was enriched in ${ }^{15} \mathrm{~N}$ compared to that of the Southern and Western Lagoon manatees. The Western Lagoon is part of the Southern Lagoon, while the Northern Lagoon is a more distinct body of water (Fig. 1). It is possible that regional differences in nitrogen input from surrounding terrestrial sources had an effect on the nitrogen signatures of lagoon vegetation.

Enriched carbon ratios in the skin of manatees sampled in Puerto Rico indicate that seagrasses are the primary component of their diet. The lack of significant regional differences in carbon ratios suggests that this reliance on seagrasses is consistent among manatees in Puerto Rico. However, we found significant regional differences in nitrogen ratios in the skin of Puerto Rican manatees. As in the Belize analysis, it is possible that differences in coastal development, pollution, and agriculture had an effect on nitrogen input in the surrounding waters. The stable isotope results for freeranging manatees agree with the hypothesis of Lefebvre et al. (2000) that due to thermally driven seasonal migrations, Florida manatees are less specialized grazers than manatees in Puerto Rico, for which seagrasses are the main diet component available.

There were no sex-based differences in isotopic composition of Florida or Antillean manatee skin. In the manatee social system, there are no separate breeding or feeding grounds as in other systems in which we may expect to see sex-based differences in diet and thus isotopic composition of tissues. Additionally, no differences were found in stable carbon or nitrogen isotope signatures in Florida manatee skin based on the collection month. Skin samples were collected mainly during the months of November, December, and January. This sampling period coincided with the large number of manatees aggregated at warm water sources. In general, all manatee skin sampling was opportunistic, so it does not necessarily mean that a manatee sampled in November arrived at a warm water refuge earlier than a manatee sampled in January. It is also unknown how long each manatee spent in the refuge or whether it left, traveling a long distance (giving it access to alternative diet sources) and then returned again. For these reasons, it is understandable that we do not see a progression towards a greater number of manatee skin signatures representative of the vegetation available near the refuge over time.

Seasonal differences in $\delta^{13} \mathrm{C}$ and/or $\delta^{15} \mathrm{~N}$ values were found within the skin of Belize manatees; however, results for manatees from the Drowned Cayes and Western Lagoon should be interpreted with caution due to small sample sizes. Reported differences may be due to seasonal changes in manatee feeding, habitat, and/or seasonal variability in the stable isotope ratios of aquatic plants, the latter 2 of which have been pre- viously documented in Belize manatees (Self-Sullivan et al. 2003) and Florida aquatic plants, respectively (Anderson \& Fourqurean 2003, present study).

There was no difference in $\delta^{13} \mathrm{C}$ or $\delta^{15} \mathrm{~N}$ values in manatee skin between any of the 3 age classes for Florida or Antillean manatees. Calves $(<176 \mathrm{~cm})$ are considered nutritionally dependent, but manatees up to body lengths of $260 \mathrm{~cm}$ may nurse in addition to feeding on aquatic vegetation (O'Shea et al. 1985). Most calves that were sampled were $<170 \mathrm{~cm}$, near the calf/subadult division. It is likely that these manatees were already feeding on aquatic vegetation and possibly only nursing occasionally. Nursing animals, consuming milk derived from the mother's tissues, are in essence feeding at a higher trophic level (e.g. Fogel et al. 1989). Even skin from the 2 smallest manatees sampled (both body lengths $=130 \mathrm{~cm}$, Florida) did not have enriched $\delta^{15} \mathrm{~N}$ values (5.8 and $4.3 \%$ ) compared to those of longer body lengths. Finally, variability in nitrogen signatures found for aquatic plants in Florida ( -2.9 to $10.3 \%$ ) makes it difficult to assess possible differences in trophic level between nursing and weaned manatees. The age class division between subadults and adults is a gross estimate based on sexual maturity and is mainly used to assess manatee mortality rates and population structure (O'Shea et al. 1985). It has no relation to any specific feeding distinction.

\section{Conservation implications}

Fine-scale interpretation of our diet modeling results warrants caution; however, we can make general conclusions relevant to manatee conservation. Seagrasses were a required diet component for Florida manatees from all regions sampled in the present study and likely made up more than $50 \%$ of the diet of manatees wintering at the Big Bend Power Plant in Tampa Bay, Warm Mineral Springs near Charlotte Harbor, and Port of the Islands in Ten Thousand Islands. In an effort to provide more suitable habitat for Florida manatees, efforts should focus on reducing further losses of seagrass beds especially near the regions mentioned above. The range of individual variation in $\delta^{13} \mathrm{C}$ and $\delta^{15} \mathrm{~N}$ values in Florida manatee skin within a given location also suggests that warm water refuges are used by manatees from different geographic regions. Consequently, there may not be one single conservation solution regarding feeding habitat that caters to all manatees wintering at any of the specific locations in this study. It is also apparent that seagrasses are a critical component in the diet of Antillean manatees in Belize and even more so for those in Puerto Rico; therefore, regional management plans should emphasize protection of seagrass beds in those areas as well. 
Acknowledgements. We thank M. Ross and B. Chittick for assistance with manatee skin sample collections, and we are grateful for funding from the University of Central Florida (UCF) Department of Biology and Graduate Studies to C.D.A.-S. and a UCF Provosts Research Enhancement Award to G.A.J.W. Manatee research was carried out under UCF Institutional Animal Care and Use Committee protocol 02-09W, US Fish and Wildlife Service (USFWS) permit nos. MA056326 issued to G.A.J.W. and MA791721 issued to R.K.B., and Belize Forestry Department scientific collection and research permits $\mathrm{CD} / 72 / 02$ and $\mathrm{CD} / 60 / 3 / 03$ with subsequent amendments issued to N. Auil and J. A. Powell. Plant samples were collected under Florida Department of Environmental Protection collection permit no. 1753 issued to G.A.J.W. We thank J. Roth and J. Weishampel for comments on the manuscript, J. Fauth for assistance with statistical analyses, and 3 anonymous reviewers for their comments. Additional thanks to T. Maddox, R. Harris, R. Runnels, T. Doyle, K. Fuhr, J. Greenawalt, L. Hoopes, A. Stephens, M. DiPiazza, N. Browning, J. Stanley, and T. A. M. Worthy for field and lab assistance. Use of trade or product names does not imply endorsement by the US Government.

\section{LITERATURE CITED}

Alves-Stanley CD, Worthy GAJ (2009) Carbon and nitrogen stable isotope turnover rates and diet-tissue discrimination in Florida manatees (Trichechus manatus latirostris). J Exp Biol 212:2349-2355

Ames AL, VanVleet ES, Sackett WM (1996) The use of stable carbon isotope analysis for determining the dietary habits of the Florida manatee, Trichechus manatus latirostris. Mar Mamm Sci 12:555-563

Anderson WT, Fourqurean JW (2003) Intra- and interannual variability in seagrass carbon and nitrogen stable isotopes from south Florida, a preliminary study. Org Geochem 34: 185-194

Auil NE (2004) Abundance and distribution trends of the West Indian manatee in the coastal zone of Belize: implications for conservation. MS thesis, Texas A\&M University, College Station, TX

Auil NE, Powell JA, Bonde RK, Anderwin K, Galves J (2007) Belize Conservation Programme 10 year summary to Liz Claiborne Art Ortenberg Foundation, Wildlife Trust, New York

Bardonnet A, Riera P (2005) Feeding of glass eels (Anguilla anguilla) in the course of their estuarine migration: new insights from stable isotope analysis. Estuar Coast Shelf Sci 63:201-209

Bengtson JL (1983) Estimating food-consumption of freeranging manatees in Florida. J Wildl Manag 47:1186-1192

Best RC (1981) Foods and feeding habits of wild and captive Sirenia. Mammal Rev 11:3-29

Bossart GD, Meisner RA, Rommel SA, Ghin S, Jensen AB (2003) Pathological features of the Florida manatee cold stress syndrome. Aquat Mamm 29:9-17

Boutton TW (1991) Stable carbon isotope ratios of natural materials: II. Atmospheric, terrestrial, marine, and freshwater environments. In: Coleman DC, Fry B (eds) Carbon isotope techniques. Academic Press, San Diego, CA, p 173-185

Converse LJ, Fernandes PJ, Macwilliams PS, Bossart GD (1994) Hematology, serum chemistry, and morphometric reference values for Antillean manatees (Trichechus manatus manatus). J Zoo Wildl Med 25:423-431

> Deniro MJ, Epstein S (1978) Influence of diet on distribution of carbon isotopes in animals. Geochim Cosmochim Acta
42:495-506

Deniro MJ, Epstein S (1981) Influence of diet on the distribution of nitrogen isotopes in animals. Geochim Cosmochim Acta 45:341-351

Fogel ML, Tuross N, Owsley DW (1989) Nitrogen isotope tracers of human lactation in modern and archeological populations. In: Annual report of the Director, Geophysical Laboratory 1988-1989. Carnegie Institution, Washington, DC, p 111-117

Fry B (1981) Natural stable carbon isotope tag traces Texas shrimp migrations. Fish Bull 79:337-345

Fry B, Lutes R, Northam M, Parker PL, Ogden J (1982) A C-13/C-12 comparison of food webs in Caribbean seagrass meadows and coral reefs. Aquat Bot 14:389-398

FWC (Florida Fish and Wildlife Conservation Commission) (2009) FWC records high counts during statewide manatee survey. Available at: www.myfwc.com/NEWSROOM/ 09/statewide/News_09_X_ManateeSynoptic.htm

Hartman DS (1979) Ecology and behavior of the manatee (Trichechus manatus) in Florida. Am Soc Mammal Spec Publ No. 5

> Hemminga MA, Mateo MA (1996) Stable carbon isotopes in seagrasses: variability in ratios and use in ecological studies. Mar Ecol Prog Ser 140:285-298

$>$ Hobson KA (1999) Tracing origins and migration of wildlife using stable isotopes: a review. Oecologia 120:314-326

> Hobson KA, Schell DM, Renouf D, Noseworthy E (1996) Stable carbon and nitrogen isotopic fractionation between diet and tissues of captive seals: implications for dietary reconstructions involving marine mammals. Can J Fish Aquat Sci 53:528-533

> Irvine AB (1983) Manatee metabolism and its influence on distribution in Florida. Biol Conserv 25:315-334

Iverson SJ, Frost KJ, Lowry LF (1997) Fatty acid signatures reveal fine scale structure of foraging distribution of harbor seals and their prey in Prince William Sound, Alaska. Mar Ecol Prog Ser 151:255-271

Kelly JF (2000) Stable isotopes of carbon and nitrogen in the study of avian and mammalian trophic ecology. Can J Zool 78:1-27

Kroening SE (2004) Streamflow and water-quality characteristics at selected sites of the St. Johns River in Central Florida, 1933 to 2002. Rep No. 2004-5177, US Geological Survey Scientific Investigations, Reston, VA

> Laidre KL, Heide-Jorgensen MP, Dietz R, Hobbs RC, Jorgensen OA (2003) Deep-diving by narwhals Monodon monoceros: differences in foraging behavior between wintering areas? Mar Ecol Prog Ser 261:269-281

Lefebvre LW, O'Shea TJ, Rathbun GB, Best RC (1989) Distribution, status, and biogeography of the West Indian manatee. In: Woods CA (ed) Biogeography of the West Indies. Sandhill Crane Press, Gainesville, FL, p 567-610

Lefebvre LW, Ackerman BB, Portier KM, Pollock KH (1995) Aerial survey as a technique for estimating trends in manatee population size-problems and prospects. In: O'Shea TJ, Ackerman BB, Percival HF (eds) Population biology of the Florida manatee. Information and Technology Report 1, National Biological Service, Washington, DC, p 63-74

Lefebvre LW, Reid JP, Kenworthy WJ, Powell JA (2000) Characterizing manatee habitat use and seagrass grazing in Florida and Puerto Rico: implications for conservation and management. Pac Conserv Biol 5:289-298

> Marshall CD, Kubilis PS, Huth GD, Edmonds VM, Halin DL, Reep RL (2000) Food-handling ability and feeding-cycle length of manatees feeding on several species of aquatic plants. J Mammal 81:649-658 
Mignucci-Giannoni AA, Beck CA (1998) The diet of the manatee (Trichechus manatus) in Puerto Rico. Mar Mamm Sci 14:394-397

Mignucci-Giannoni AA, Montoya-Ospina RA, Jimenez-Marrero NM, Rodriguez-Lopez MA, Williams EH, Bonde RK (2000) Manatee mortality in Puerto Rico. Environ Manag 25:189-198

Minagawa M, Wada E (1984) Stepwise enrichment of ${ }^{15} \mathrm{~N}$ along food chains: further evidence and the relation between $\delta^{15} \mathrm{~N}$ and animal age. Geochim Cosmochim Acta 48:1135-1140

Moncreiff CA, Sullivan MJ (2001) Trophic importance of epiphytic algae in subtropical seagrass beds: evidence from multiple stable isotope analyses. Mar Ecol Prog Ser 215: 93-106

> Morales-Vela B, Olivera-Gomez D, Reynolds JE, Rathbun GB (2000) Distribution and habitat use by manatees (Trichechus manatus manatus) in Belize and Chetumal Bay, Mexico. Biol Conserv 95:67-75

O'Shea TJ, Salisbury CA (1991) Belize - a last stronghold for manatees in the Caribbean. Oryx 25:156-164

O'Shea TJ, Beck CA, Bonde RK, Kochman HI, Odell DK (1985) An analysis of manatee mortality patterns in Florida, 1976-81. J Wildl Manag 49:1-11

Olivera-Gomez LD, Mellink E (2005) Distribution of the Antillean manatee (Trichechus manatus manatus) as a function of habitat characteristics, in Bahia de Chetumal, Mexico. Biol Conserv 121:127-133

Ortiz RM, Worthy GAJ, MacKenzie DS (1998) Osmoregulation in wild and captive West Indian manatees (Trichechus manatus). Physiol Zool 71:449-457

Ortiz RM, Worthy GAJ, Byers FM (1999) Estimation of water turnover rates of captive West Indian manatees (Trichechus manatus) held in fresh and salt water. J Exp Biol 202:33-38

Peterson BJ, Fry B (1987) Stable isotopes in ecosystem studies. Annu Rev Ecol Syst 18:293-320

Phillips DL, Gregg JW (2001) Uncertainty in source partitioning using stable isotopes. Oecologia 127:171-179

Phillips DL, Gregg JW (2003) Source partitioning using stable isotopes: coping with too many sources. Oecologia 136: 261-269

Phillips DL, Koch PL (2002) Incorporating concentration dependence in stable isotope mixing models. Oecologia 130:114-125

Quintana-Rizzo E, Reynolds J III (2007) Regional management plans for the West Indian manatee (Trichechus manatus). Caribbean Environment Programme, United

Editorial responsibility: Yves Cherel,

Villiers-en-Bois, France
Nations Environment Programme, CEP Tech Rep. Available at: http://cep.unep.org/events-and-meetings/4th-spawstac-1/IV\%20SPAW\%20STAC\%20(WG31)/English/WG31inf5en.pdf

Rau GH, Ainley DG, Bengtson JL, Torres JJ, Hopkins TL (1992) ${ }^{15} \mathrm{~N} /{ }^{14} \mathrm{~N}$ and ${ }^{13} \mathrm{C} /{ }^{12} \mathrm{C}$ in Weddell Sea birds, seals, and fish: implications for diet and trophic structure. Mar Ecol Prog Ser 84:1-8

Reich KJ, Worthy GAJ (2006) An isotopic assessment of the feeding habits of free-ranging manatees. Mar Ecol Prog Ser 322:303-309

Self-Sullivan C, Smith GW, Packard JM, LaCommare KS (2003) Seasonal occurrence of male Antillean manatees (Trichechus manatus manatus) on the Belize Barrier Reef. Aquat Mamm 29:342-354

Sinclair EH, Zeppelin TK (2002) Seasonal and spatial differences in diet in the western stock of Steller sea lions (Eumetopias jubatus). J Mammal 83:973-990

Slone DH, Reid JP, Bonde RK, Butler SM, Stith BM (2006) Summary of West Indian manatee (Trichechus manatus) tracking by USGS-FISC Sirenia Project in Puerto Rico, with additional information on aerial surveys, carcass recovery, and genetics research, USGS-FISC, Gainesville, FL

Spitz J, Rousseau Y, Ridoux V (2006) Diet overlap between harbour porpoise and bottlenose dolphin: an argument in favour of interference competition for food? Estuar Coast Shelf Sci 70:259-270

UNEP Caribbean Environment Programme (1995) Regional management plan for the West Indian manatee, Trichechus manatus. Report No. 35, Kingston, Jamaica

USFWS (US Fish and Wildlife Service) (2001) Florida manatee recovery plan, (Trichechus manatus latirostris), 3rd revision. USFWS, Atlanta, GA

Vanderklift MA, Ponsard S (2003) Sources of variation in consumer-diet $\delta^{15} \mathrm{~N}$ enrichment: a meta-analysis. Oecologia 136:169-182

Vizzini S, Mazzola A (2006) The effects of anthropogenic organic matter inputs on stable carbon and nitrogen isotopes in organisms from different trophic levels in a southern Mediterranean coastal area. Sci Total Environ 368: 723-731

Vizzini S, Sara G, Mateo MA, Mazzola A (2003) $\delta^{13} \mathrm{C}$ and $\delta^{15} \mathrm{~N}$ variability in Posidonia oceanica associated with seasonality and plant fraction. Aquat Bot 76:195-202

Worthy GAJ, Miculka TA, Wright SD (2000) Manatee response to cold: How cold is too cold? In: Perkins W (ed) Florida manatees and warm water: Proceedings of the Warm Water Workshop. USFWS, Jacksonville, FL, p 1-6

Submitted: November 18, 2008; Accepted: December 3, 2009 Proofs received from author(s): February 22, 2010 